\title{
ANALISIS PERMINTAAN KREDIT MODAL USAHA PADA BANK PEMERINTAH DI SUMATERA UTARA
}

\author{
Putri Sari Silaban \\ Program Pascasarjana Ilmu Ekonomi Universitas Negeri Medan \\ JI. Williem Iskandar Ps. V Medan 20221, Telp. +6261-6613365 \\ Email: poetrisilaban@yahoo.com
}

\begin{abstract}
This research aims to analyze the influence of GDP, interest rate, $C P I$ and the amount of deposits to the credit demand of venture capital to the state bank in North Sumatra simultaneously and partially. The data used are secondary data sourced from North Sumatra Bank of Indonesia variables namely GDP, interest rate, CPI and the number of deposit and loan capital of North Sumatra Province, on a quarterly basis from 2003 till, 2011. Data analysis was performed using OLS (Ordinary Least Square) with multiple linear regression models estimated with the help of the program Eviews 5.1. The results of this research can be concluded that simultaneous co-GDP variables constant change, the consumer price index, interest rate, and the amount of deposits significantly affect credit demand in the capital of North Sumatra Province. Furthermore, partially concluded that variables GDP, and the amount of deposits a positive effect on demand for capital loans, while the $\mathrm{CPI}$ and the variable mortgage interest rates negatively affect credit demand in the capital of North Sumatra Province. The results also showed that the most dominant variable effect on credit demand in the province of North Sumatra capital is the amount of deposits.
\end{abstract}

Key words: Modern Market, Tradisional Market, MSMEs, Partnership

\section{PENDAHULUAN}

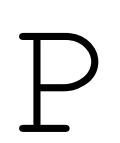

erekonomian merupakan sektor yang sangat penting dan menjadi salah satu fokus pemerintah dalam membuat berbagai kebijakan untuk mencapai kesejahteraan. Mengingat sangat pentingnya sektor perekonomian ini sehingga dalam menentukan dan memutuskan setiap kebijakan harus mempertimbangkan segala aspek yang mungkin dapat mempengaruhi perekonomian baik yang bersifat positif maupun yang bersifat negatif. Perekonomian suatu negara disamping memerlukan program yang terencana dan terarah untuk mencapai sasaran, faktor lainnya adalah dibutuhkan modal atau dana pembangunan yang cukup besar. Kelangkaan modal merupakan masalah utama dalam dunia usaha karena modal sebagai unsur esensial dalam mendukung peningkatan produktivitas dan taraf hidup masyarakat, maka ketersediaan modal dapat membatasi ruang gerak aktivitas dunia. Untuk itu, kesulitan permodalan menjadi sangat menarik untuk dibahas terkait dengan 
akses dana perbankan terhadap dunia usaha. Rendahnya daya serap usaha terhadap kredit perbankan tersebut sebagai akibat berbagai kendala yang dihadapi.

Perbankan sebagai salah satu fungsi intermediasi, berperan dalam mendorong tingkat pertumbuhan ekonomi dan memperluas kesempatan kerja melalui penyediaan sejumlah dana pembangunan dan dunia usaha. Pihak - pihak yang kelebihan dana, baik perorangan, badan usaha, yayasan maupun lembaga pemerintah dapat menyimpan kelebihan dananya di bank dalam bentuk rekening giro, tabungan maupun deposito berjangka sesuai kebutuhan dan prefensinya. Khusus untuk dunia usaha, dana yang yang diberikan oleh bank adalah dalam bentuk kredit. Jumlah permintaan kredit pada suatu bank dipengaruhi oleh berbagai faktor, baik dari sisi debitur maupun dari sisi kreditur (perbankan) itu sendiri. Permintaan kredit dari sisi debitur (dunia usaha) dipengaruhi oleh adanya upaya untuk meningkatkan aktivitas usaha, baik dalam bentuk investasi maupun modal kerja. Pemberian kredit perbankan yang sepenuhnya diperoleh dari sumber dana masyarakat dan dipergunakan untuk kegiatan perekonomian.

Dalam upaya memperkuat posisi perekonomian, kredit seringkali dijadikan sebagai alat untuk membantu para pelaku usaha kecil, menengah, maupun besar dengan asumsi pemberian kredit dapat meningkatkan pendapatan. Lemahnya permodalan pelaku usaha telah disadari oleh pemerintah dan akhirnya terdorong untuk meluncurkan beberapa program kredit modal usaha. Oleh karena itu, sistem perkreditan modal usaha merupakan salah satu sumber pendanaan yang diberikan oleh jasa perbankan bagi pelaku usaha dalam memenuhi kebutuhan finansialnya. Adapun jasa yang diberikan oleh perbankan adalah dengan memberikan fasilitas kredit, seperti kredit program pemerintah, kredit investasi, kredit konsumtif, kredit ekspor dan kredit modal kerja.

Adapun perkembangan secara umum jumlah kredit yang diberikan perbankan di provinsi Sumatera Utara khususnya dari kuartal pertama tahun 2006 sampai dengan kuartal keempat tahun 2011 pada gambar 1.1, diketahui bahwa pinjaman modal kerja yang diberikan oleh Bank secara umum cenderung meningkat. Menurunnya posisi pinjaman kredit ini khususnya terjadi pada kuartal 2 tahun 2010 yakni sebesar $4.852,12$ milyar atau menurun sebanyak 14,65 persen dari kuartal sebelumnya. Selanjutnya penurunan jumlah kredit juga terjadi pada kuartal 4 tahun 2010 sebesar 4.848,84 milyar atau menurun sebesar 13,82 persen.

Sementara itu, jika ditinjau dari pinjaman kredit tahun 2003, jumlah kredit modal tertinggi terjadi pada tahun 2011 kuartal 4 sebesar 46.788,76 milyar dari kuartal sebelumnya sebesar 40.965,80 milyar atau meningkat sebanyak 14,21 persen. Sedangkan jumlah kredit modal terendah terjadi pada tahun 2003 kuartal 1 sebesar 7.046,08 milyar. Artinya jika ditotal dari tahun amatan tersebut yakni tahun 2003 kuartal 1 hingga tahun 2011 kuartal 4, maka telah terjadi perkembangan sebesar $39.742,68$ milyar atau telah berkembangan sangat pesat sebesar 564,03 persen.

Kegiatan penghimpunan dana yang berupa tabungan, giro dan deposito merupakan beberapa kegiatan operasional perbankan yang wajib dilakukan. Penghimpunan dana

$$
\text { QE Journal |Vol.01 - No.03 - } 15
$$


(tabungan, deposito dan giro) oleh pihak bank merupakan kegiatan operasional dalam memperoleh dana dari masyarakat yang nantinya digunakan sebagai penyediaan dana untuk keperluan penyaluran kredit. Semakin besar jumlah penghimpunan dana maka semakin besar jumlah kredit yang disalurkan dapat menjadikan perolehan laba yang semakin besar pula.

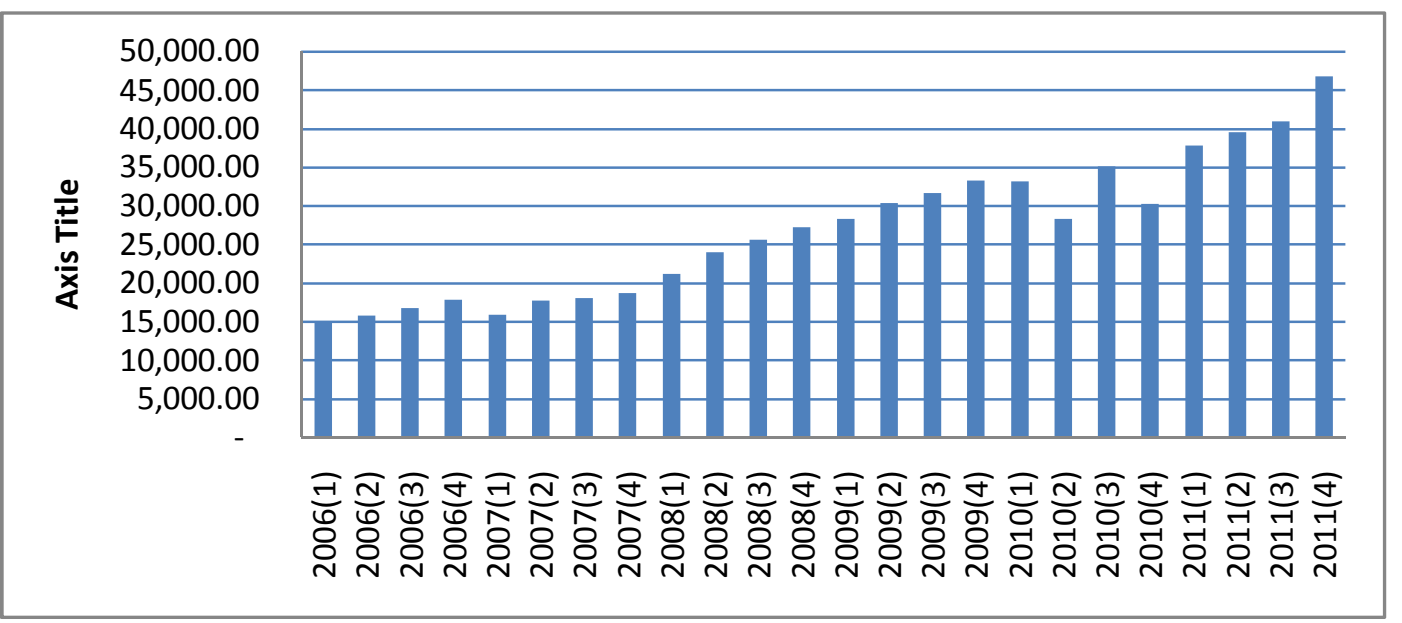

Sumber: Bank Indonesia, SEKDA 2006-2011:41-42

Gambar: 1.1 Posisi Pinjaman Modal Kerja Usaha (keadaan dalam Milyar Rupiah)

Sumber dana masyarakat dari tabungan dan deposito cenderung akan lebih banyak dialokasikan kepada kegiatan kredit karena kegiatan kredit bersifat lebih produktif. Kredit bersifat produktif berarti menghasilkan berupa pendapatan bunga atas kredit yang sekaligus merupakan pendapatan terbesar bagi bank yang akhirnya berpengaruh terhadap kinerja rentabilitas bank. Deposito atau simpanan berjangka juga merupakan salah satu sumber dana bagi bank yang dapat dialokasikan sebagi sumber bagi pendanaan kredit. Semakin besar jumlah deposito yang dapat dihimpun oleh bank maka semakin besar pula jumlah kredit yang dapat disalurkan oleh bank.

Modal kredit ini juga memiliki hubungan positif dengan jumlah deposito masyarakat. Banyaknya deposito yang dihasilkan dalam suatu daerah, maka akan memungkinkan kemudahan untuk memberikan dana pinjaman yang lebih banyak dan lebih merata kepada pelaku usaha. Tentunya hal ini akan menggiatkan sektor-sektor perekonomian suatu daerah. Bila kredit modal dikaitkan dengan PDRB, maka modal kredit perbankan memiliki hubungan positif dengan produk domestik regional bruto (PDRB). PDRB merupakan jumlah nilai tambah yang dihasilkan oleh seluruh nilai barang dan jasa oleh seluruh unit ekonomi di suatu wilayah. Bahwa PDRB berhubungan erat dengan permintaan kredit modal kerja. Adanya kenaikan PDRB, maka akan menggiatkan sektor-sektor perekonomian suatu daerah. Berkembangnya sektor-sektor perekonomian suatu daerah, maka tingkat kebutuhan akan modal akan semakin besar. Hal ini tentunya dapat disikapi dengan semakin besarnya kebutuhan akan kredit modal kerja. 
Kredit modal usaha memiliki hubungan negatif dengan suku bunga pinjaman/kredit. Suku bunga kredit adalah harga/biaya dari penggunaan dana yang tersediauntuk dipinjamkan. Suku bunga kredit berpengaruh negatif terhadap permintaan kredit. Menurut Samuelson dan Nordhaus (2004:35), bahwa permintaan kredit dipengaruhi oleh suku bunga (biaya untuk memegang uang), dimana semakin tinggi suku bunga kredit, maka permintaan kredit akan menurun. Artinya semakin tinggi suku bunga kredit yang menceminkan semakin mahalnya biaya maka akan menurunkan permintaan kredit, dan sebaliknya semakin rendah suku bunga kredit yang mencerminkan semakin murahnya biaya akan meningkatkan permintaan kredit. Fenomena ini mencerminkan bahwa masih tingginya suku bunga kredit saat ini menjadi salah satu pertimbangan bagi dunia usaha dalam melakukan permohonan kredit kepada bank.

Inflasi memiliki hubungan negatif dengan permintaan kredit perbankan, dikarenakan inflasi berarti juga kenaikan harga. Semakin naiknya harga, maka seseorang akan enggan untuk melakukan usaha, sehingga permintaan pengajuan kredit akan semakin rendah. Oleh karena itu, maka dengan adanya penurunan inflasi, maka permintaan akan kredit juga akan semakin meningkat.

Maka, tujuan yang ingin dicapai dalam penelitian ini adalah untuk mengetahui pengaruh PDRB, suku bunga kredit, IHK dan jumlah deposito terhadap permintaan kredit modal kerja di Provinsi Sumatera Utara secara simultan dan parsial.

Permintaan adalah kombinasi harga dan jumlah suatu barang yang ingin di beli konsumen pada berbagai tingkat harga. Permintaan dipengaruhi oleh pendapatan dan harga barang tersebut. Sedangkan hukum permintaan pada dasarnya mengatakan bahwa jika harga barang naik tetapi pendapatan tetap maka permintaan akan barang tersebut akan tgurun dan jika harga barang turun tetapi pendapatan tetap maka permintaan akan barang tersebut naik.

Aplikasi hukum permintaan terhadap perkreditan perbankan dimana tingkat suku bunga kredit yang rendah menunjukkan kondisi perekonomian perbankan sehingga kredit yang diminta oleh masyarakat akan meningkat. Sebaliknya, tingkat suku bunga yang tinggi menunjukkan menurunnya kondisi perekonomian perbankan sehingga kredit yang diminta oleh masyarakan akan menurun.

Sedangkan kredit itu sendiri dalam Manurung-Manurung (2009:365) merupakan pinjaman yang diberikan individu atau perusahaan dengan spesifikasi waktu dan pembayaran tertentu. Pinjaman atau kredit perbankan merupakan sumber pendapatan bank dan sumber pendanaan investasi perusahaan.

\section{METODE PENELITIAN}

Dalam melaksanakan penelitian ini penulis mengambil tempat penelitian di daerah Tingkat I di Sumatera Utara, ruang lingkup penelitian ini adalah untuk melihat bagaimana pengaruh variabel suku bunga kredit, IHK, jumlah deposito dan PDRB terhadap permintaan kredit modal usaha pada bank pemerintah di Provinsi Sumatera Utara. 
Sumber data yang digunakan dalam penelitian ini adalah data sekunder. Data sekunder adalah data yang diperoleh dari sumber yang tidak langsung dengan obyek yang diteliti atau sumber-sumber lain yang berkaitan dengan penelitian dimana data ini diperoleh dari instansi atau lembaga terkait. Data diperoleh dari buku kajian ekonomi regional Sumatera Utara, statistik ekonomi keuangan daerah Sumatera Utara dan BPS.

Adapun data sekunder yang dipergunakan dalam penelitian ini adalah variabel PDRB konstan, suku bunga kredit, IHK, jumlah deposito dan total kredit modal di Provinsi Sumatera Utara secara kuartalan dari tahun 2003 sampai tahun 2011.

Spesifikasi model yang digunakan di adaptasi dari beberapa penelitian sebelumnya dengan melakukan penyesuaian-penyesuaian yang dianggap akan memberikan hasil yang lebih baik untuk menjelaskan faktor-faktor yang mempengaruhi permintaan kredit modal di Provinsi Sumatera Utara dengan menggunakan analisis regresi berganda dengan metode Ordinary Least Square (OLS) atau metode kuadrat terkecil biasa. Untuk itu fungsi-fungsi yang digunakan dalam penelitian ini adalah:

$$
K M=f(P D R B K, J D, I H K, S B K)
$$

Dari persamaan 1, kemudian ditransformasikan model tersebut kedalam bentuk logaritma dengan hasil sebagai berikut:

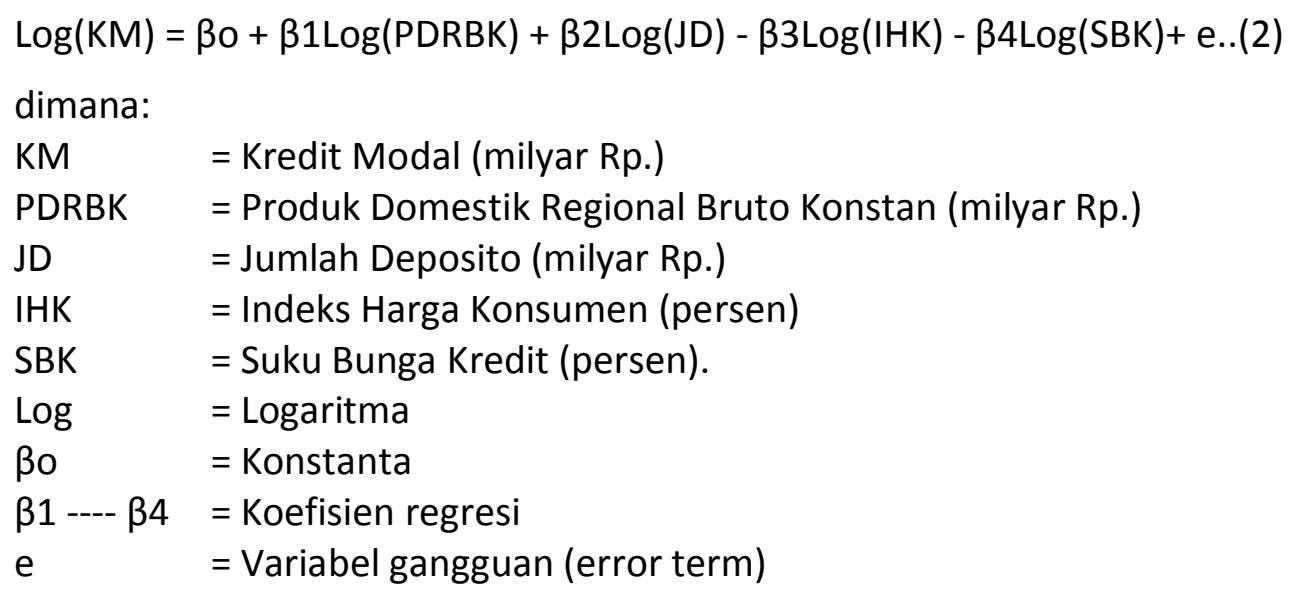

\section{PEMBAHASAN}

\section{Pemilihan Model}

Pengujian regresi yang digunakan dalam penelitian ini menggunakan regresi data kuartalan dengan pendekatan model OLS (ordinary least square). Penelitian ini dicerminkan melalui model estimasi regresi linear berganda yang didasarkan atas hasil pengolahan data dengan menggunakan program Eviews 5.1. yang ditunjukkan pada persamaan sebagai berikut: 


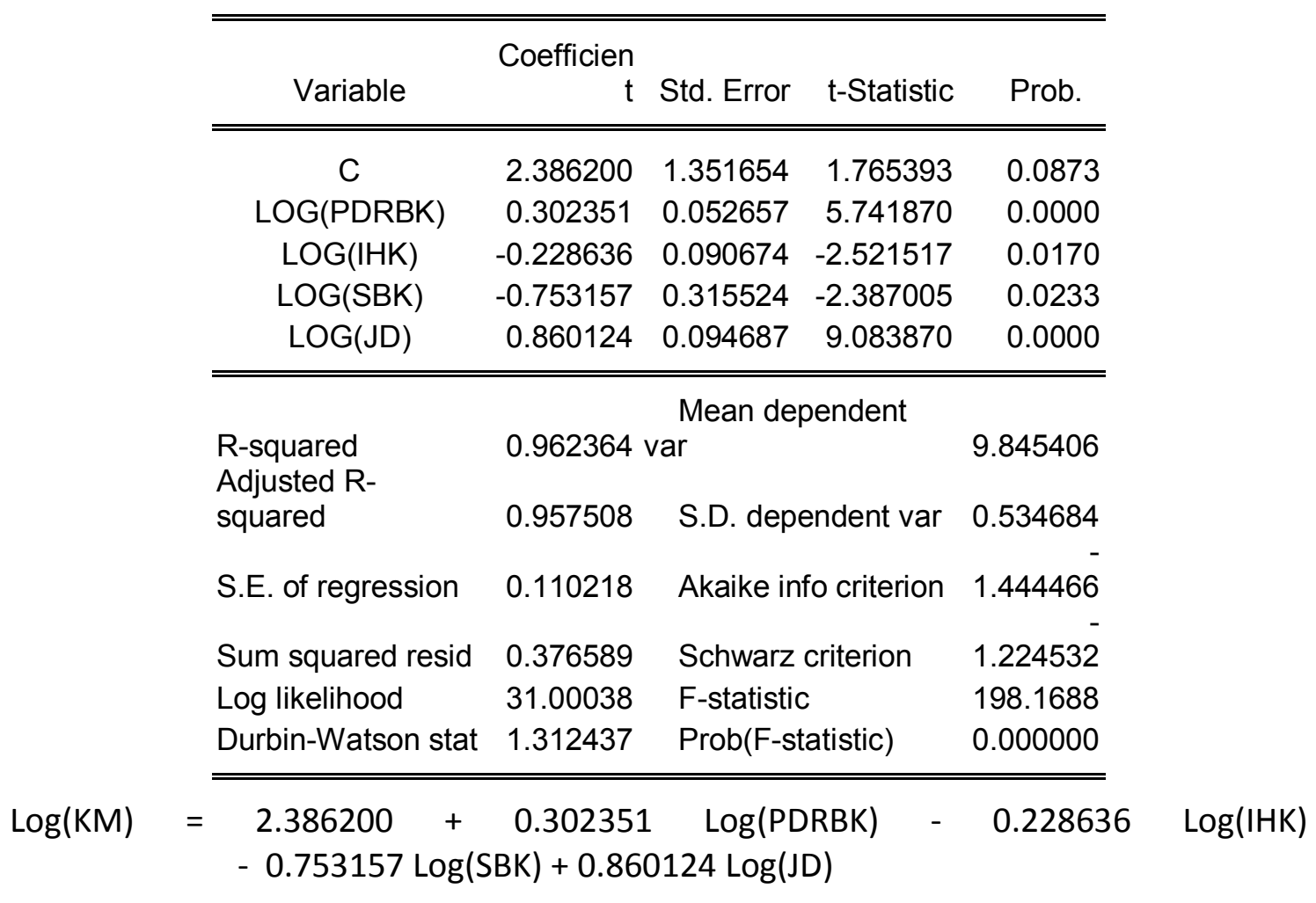

Berdasarkan model tersebut diketahui bahwa variable suku bunga kredit, indeks harga konsumen, jumlah deposito dan PDRB berpengaruh terhadap permintaan kredit modal di Provinsi Sumatera Utara.

Berdasarkan besaran koefisien diatas, maka dapat dijelaskan sebagai berikut:

a. Konstanta sebesar 2,3862 menunjukkan bahwa jika variabel bebas seperti PDRB, IHK, suku bunga kredit dan jumlah deposito adalah konstan, maka permintaan kredit modal akan tetap sebanyak 2,3862 persen.

b. Setiap kenaikan PDRB sebesar 1 persen, maka akan menaikkan besaran permintaan kredit modal di Provinsi Sumatera Utara sebesar 0.302351 persen.

c. Setiap kenaikan IHK sebesar 1 persen, maka akan menurunkan besaran permintaan kredit modal di Provinsi Sumatera Utara sebesar 0.228636 persen.

d. Setiap kenaikan suku bunga kredit sebesar 1 persen, maka akan menurunkan besaran permintaan kredit modal di Provinsi Sumatera Utara sebesar 0.753157 persen.

e. Setiap kenaikan jumlah deposito sebesar 1 persen, maka akan menaikkan besaran permintaan kredit modal di Provinsi Sumatera Utara sebesar 0.860124 persen.

\section{Uji Multikolineariti}

Sesuai dengan metode penelitian, multikolineariti dalam penelitian ini diuji dengan menggunakan VIF untuk mendeteksi adanya multikolineariti dengan hasil sebagai berikut: 
Tabel 4.2 Korelasi Matriks dan Variance Inflating Factor

\begin{tabular}{|c|c|c|c|c|}
\hline \multicolumn{5}{|c|}{ MATRIX CORRELATION } \\
\hline & Log(PDRBK) & $\log (J D)$ & $\log (\mathrm{IHK})$ & $\log (\mathrm{SBK})$ \\
\hline Log(PDRBK) & 1 & 0.720 & -0.466 & -0.710 \\
\hline $\log (J D)$ & 0.720 & 1 & -0.271 & -0.717 \\
\hline $\log ($ IHK) & -0.466 & -0.271 & 1 & 0.604 \\
\hline $\log (\mathrm{SBK})$ & -0.710 & -0.717 & 0.604 & 1 \\
\hline \multicolumn{5}{|c|}{ VARIANCE INFLATING FACTOR } \\
\hline & Log(PDRBK) & $\log (J D)$ & $\log (\mathrm{IHK})$ & $\log (S B K)$ \\
\hline Log(PDRBK) & 1 & 3.571 & 0.682 & 0.585 \\
\hline $\log (J D)$ & 3.571 & 1 & 0.787 & 0.582 \\
\hline $\log ($ IHK) & 0.682 & 0.787 & 1 & 2.525 \\
\hline Log(SBK) & 0.585 & 0.582 & 2.525 & 1 \\
\hline
\end{tabular}

Berdasarkan Tabel 4.2. diatas dengan kriteria bahwa jika nilai VIF $<10$ artinya di dalam model tidak terdapat multikolinearitas, maka dapat disimpulkan bahwa tidak terjadi permasalahan multikolineariti dalam data penelitian ini.

\section{Uji Autokorelasi}

Tabel 4.3. Uji Autokorelasi

Breusch-Godfrey Serial Correlation LM Test:

\begin{tabular}{llll}
\hline \hline F-statistic & 3.801239 & Prob. F(2,29) & 0.034188 \\
Obs*R-squared & 7.477341 & Prob. Chi-Square(2) & $\mathbf{0 . 0 6 3 7 8 6}$ \\
\hline \hline
\end{tabular}

Berdasarkan Tabel 4.3. diperoleh nilai prob. Obs* $R$-squared sebesar $0.063786>0.05$, maka dapat disimpulkan bahwa tidak terjadi gejala autokorelasi pada penelitian ini.

\section{Uji Normalitas}

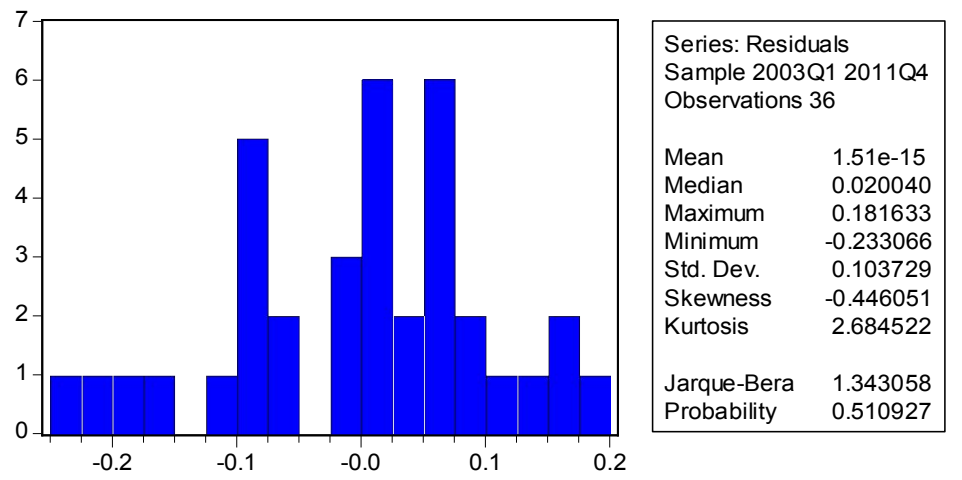

Gambar 4.4. Uji Normalitas

Berdasarkan Gambar 4.4. diperoleh nilai prob. JB sebesar $0.510927>0.05$, maka dapat disimpulkan bahwa tidak terjadi pelanggaran uji normalitas dalam penelitian ini. 


\section{Pembahasan Uji Signifikansi}

\section{a. Uji Keseluruhan Parameter (F-test)}

Secara simultan keempat variabel tersebut menunjukkan nilai $F$-Stat yang cukup tinggi yaitu 198.1688 dengan prob. sebesar $0.000<0.05$, sehingga Ho ditolak yang berarti bahwa secara bersama-sama perubahan variabel PDRB konstan, indeks harga konsumen, suku bunga kredit, dan jumlah deposito berpengaruh terhadap permintaan kredit modal di Provinsi Sumatera Utara.

\section{b. Uji Parsial (t-test)}

Uji $\mathrm{t}$ (parsial) pada penelitian ini dilakukan untuk mengetahui apakah terdapat pengaruh yang signifikan variabel PDRB konstan, indeks harga konsumen, suku bunga kredit, dan jumlah deposito berpengaruh terhadap permintaan kredit modal di Provinsi Sumatera Utara. Adapun hasil perhitungan uji parsial adalah sebagai berikut:

Tabel 4.5. Hasil Uji Hipotesis

\begin{tabular}{lllll}
\hline \hline Variable & Coefficient Std. Error & t-Statistic & Prob. \\
\hline \hline C & 2.386200 & 1.351654 & 1.765393 & 0.0873 \\
LOG(PDRBK) & 0.302351 & 0.052657 & 5.741870 & $0.0000^{* * *}$ \\
LOG(IHK) & -0.228636 & 0.090674 & -2.521517 & $0.0170^{* *}$ \\
LOG(SBK) & -0.753157 & 0.315524 & -2.387005 & $0.0233^{* *}$ \\
LOG(JD) & 0.860124 & 0.094687 & 9.083870 & $0.0000^{* * *}$ \\
\hline \hline
\end{tabular}

Sumber: Data penelitian (diolah)

Berdasarkan Tabel 4.5, dapat diperoleh diketahui bahwa:

a. Variabel PDRB konstan berpengaruh positif dan signifikan terhadap permintaan kredit modal di Provinsi Sumatera Utara dengan perolehan nilai Prob. sebesar 0.000 atau signifikan pada taraf alpha 1 persen.

b. Variabel IHK berpengaruh negatif dan signifikan terhadap permintaan kredit modal di Provinsi Sumatera Utara dengan perolehan nilai Prob. sebesar 0.0170 atau signifikan pada taraf alpha 5 persen.

c. Variabel suku bunga kredit berpengaruh negatif dan signifikan terhadap permintaan kredit modal di Provinsi Sumatera Utara dengan perolehan nilai Prob. sebesar 0.0233 atau signifikan pada taraf alpha 5 persen.

d. Variabel jumlah deposito berpengaruh positif dan signifikan terhadap permintaan kredit modal di Provinsi Sumatera Utara dengan perolehan nilai Prob. sebesar 0.000 atau signifikan pada taraf alpha 1 persen.

\section{KESIMPULAN}

Adapun kesimpulan dalam penelitian ini adalah sebagai berikut: 
1. Secara simultan keempat variabel tersebut menunjukkan nilai F-Stat yang cukup tinggi yaitu 198.1688 dengan prob. sebesar $0.000<0.05$, sehingga Ho ditolak yang berarti bahwa secara bersama-sama perubahan variabel PDRB konstan, indeks harga konsumen, suku bunga kredit, dan jumlah deposito berpengaruh terhadap permintaan kredit modal di Provinsi Sumatera Utara.

2. Secara parsial disimpulkan bahwa variabel PDRB, dan jumlah deposito berpengaruh positif terhadap permintaan kredit modal, sedangkan variabel IHK dan suku bunga kredit berpengaruh negatif terhadap permintaan kredit modal di Provinsi Sumatera Utara

3. Variabel PDRB, IHK, suku bunga kredit, dan jumlah deposito mampu menjelaskan model permintaan kredit modal di Provinsi Sumatera Utara sebesar 96,23 persen. Serta sisanya 3,77 persen dipengaruhi oleh variabel lain.

Hasil penelitian ini menunjukkan bahwa variabel yang paling dominan berpengaruh terhadap permintaan kredit modal di provinsi Sumatera Utara adalah jumlah deposito.

\section{DAFTAR PUSTAKA}

BPS Sumatera Utara. Sumatera Dalam Angka 2001-2010, Medan.

Bank Indonesia Medan (2003-2011), Laporan Tahunan Ekonomi, Publikasi, www.bi.co.id

Bank Indonesia Medan (2003-2011), Statisik Ekonomi Sumatera Utara berbagai edisi.

Badan Pusat Statistik (2000-2010), Statistik Indonesia, BPS, Sumut.

Boediono, 2001. Ekonomi Makro, Penerbit BPFE UGM-Yogyakarta.

Balogun, O.L. and S.A. Yusuf, 2011. Determinants of demand for microcredit among the rural households in South-Western States, Nigeria. J. Agric. Soc. Sci., 7: 41-48

Bernanke Ben S and Alan S Blinder. Credit, Money, Aggrerat Demand. The American Economic Review, Vol. 78, No. 2, Papers and Proceedings of the One-Hundredth Annual Meeting of the American Economic Association. (May, 1988), pp. 435439.

Chittenden F., Hall G., and Hutchinson, P., 1996, Small Firm Growth, Access to Capital Markets and Financial Structure: 17 Review of Issues and an Empirical Investigation, Small Business Economics, 8 (1), pp. 59-67

Domar, Gujarati (2003), Econometric, Erlangga. Jakarta.

Dorbunsh. Fischer dalam Sinardhin Thahir, 1997. Defenisi dan Pengertian Investasi. Jakarta.

Enderes, W. (2004), Applied Econometric Time Series, Second Edicition, John Wiley\& Sony Inc.

Halim, 2003. Pembagian Kriteria Investasi, Jurnal Makro Ekonomi. Jakarta..

QE Journal | Vol.01 - No.03 - 22 
Heshmati, Almas. 2002. The Dynamics Capital Structure: Evidence From Swedish Micro and Small Firms. Working Paper Series Economicsand Finance No.440

Heri Sudarsono, 2003. Analisis Faktor-Faktor yang mempengaurhi Investasi, Jurnal Ekonomi Kompas Nomor 7, Januari-April, hal 21-30.

Kasmir. 2002. Dasar-dasar Perbankan. PT. Rajagrafindo Persada, Jakarta.

Kisgen, J. Darren. 2006. Credit Ratings and Capital Structure. The Journal Of Finance. Vol. LXI, No. 3. June 2006

Leland; Hayne E \& Klaus Bjerre Toft. 1996. Optimal Capital Structure, Endogenous Bankruptcy, and the Term Structure of Credit Spreads. The Journal of Finance, Vol. 51, No. 3, Papers and Proceedings of the Fifty-Sixth Annual Meeting of the American Finance Association, San Francisco, California, January 5-7, 1996. (Jul., 1996), pp. 987-1019.

Mankiw, N, Greogory. 2000. Teori Makro Ekonomi. Ed. 4, Jakarta: Penerbit Erlangga.

Mankiw, N, Gregory. 2003. Teori Ekonomi Makro, Alih Bahasa: Imam Nurmawan. Erlangga. Jakarta.

Mankiw, 2000. Perbedaan Macam Investasi. Ekonomi Perencanaan Pembangunan. PT. Raja Grafindo Pustaka, Jakarta.

Manurng, Manurung. 2009. Ekonomi Keuangan dan Kebijakan Moneter. Salemba Empat. Jakarta.

Nasution, Zulkarnaen. 2010. Analisis Faktor-faktor yang Mempengaruhi Jumlah Kredit pada Bank Pemerintah di Sumatera Utara. Tesis tidak diterbitkan. Medan: Program PascaSarjana UNIMED Medan

Nopirin, (2000), Ekonomi Moneter, BPFE UGM, Yogyakarta.

Pratama Billy. 2009. Analisis Faktor-Faktor yang Mempengaruhi Kebijakan Penyaluran Kredit Perbankan.

Samuelson, Paul A. Nordhaus, William D. 1999. Makro Ekonomi: Jakarta: Erlangga.

Saragih, M. Aulia Putra. 2009. Analisis Faktor-Faktor Yang Mempengaruhi Jumlah Kredit Sektoral Di Sumatera Utara. Tesis. Medan : Program Pascasarjana Universitas Sumatera Utara.

Siregar, Togi. 2008. Analisis Faktor-Faktor Yang Menpengaruhi Permintaan Kredit Pada Bank Pemerinntah. Tesis tidak diterbitkan. Medan: Program PascaSarjana USU Medan.

Sukirno, Sadono. 2003. Pengantar Teori Makroekonomi. Edisi Kedua PT. Rajagrafindo Persada, Jakarta.

Todaro (2000), Ekonomi Untuk Negara Berkembang, Suatu pengantar, Bumi Aksara.

Todaro. 2002. Pembangunan ekonomi Dunia Ketiga, Edisi Kesembilan Bahasa Indonesia. Erlangga. Jakarta. 
Todaro, 1999. Faktor Yang Mempengaruhi Pertumbuhan Ekonomi di Dunia Ketiga. Edisi Ketujuh diterjemahan oleh Haris Munandar. Erlangga. Jakarta.

Wibowo, Arif. 2007. Pengaruh Jumlah Penghimpunan Dana Bank, Suku Bunga Kredit Modal Kerja, Dan Tingkat Laju Inflasi Terhadap Jumlah Alokasi Kredit Modal Kerja Pada Bank-Bank Umum di Indonesia.

Yunita Rahmi. 2010. Analisis Faktor-Faktor Yang Mempengaruhi Penawaran Kredit Perbankan Sumatera Utara. Tesis tidak diterbitkan. Medan:Program PascaSarjana UNIMED Medan. 